\title{
Translation of Polysemous Words in Harry Potter
}

\author{
Muthana Hameed Khalaf \\ College of Science/ University of Baghdad, Iraq \\ Email: muthana12a@yahoo.com
}

DOI: https://doi.org/10.36231/ coedw/vol30no3.15

Received 6/6/2019, Accepted 1/9/2019

\begin{abstract}
The paper pays attention to the polysemous words Harry Potter (HP). In this story, the present study exams some picking polysemic words to the extent that the translators of HP prevail to render the proposed significance as per the setting of the first content. Obviously, the picking translators in this examination were not mindful of the wonder of polysemy in the HP. They embrace a strict interpretation methodology to pass on the greater part of the polysemic sense. The method of data collection is divided into two stages. Firstly, determining the situational context of the fantasy and identifying the polysemic sense to clearly make all the contextual meanings of the source text. Secondly, reviewing the selected translation to examine how far they express the TL meaning of the polysemic sense. The present study clarifies that strict translation is reasonable to convey all components of the polysemic words. Furthermore, the translators need to utilize a selected methodology to conquer the confounding circumstance in deciphering polysemic words. In order to get a standard equivalence from multilingual dictionaries, comparative stylistic study functions to determine the contextual connotation and make the sense of polysemous notion.
\end{abstract}

Keywords: Equivalence, fantasy novels, Harry Potter, polysemy, translation

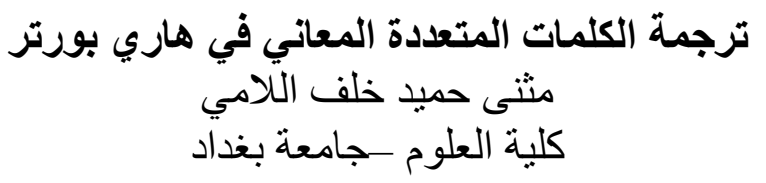

يركز البحث على الكلمات المتعددة المعاني في هاري بوتر. ففي هذه الرواية ، تفحص الدراسة الحالبة بعض الكلمات المتعددة

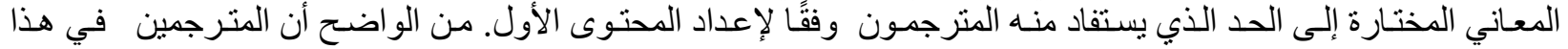

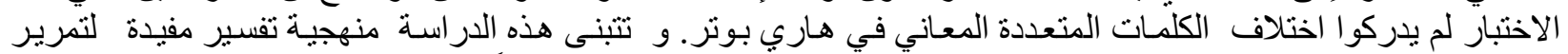

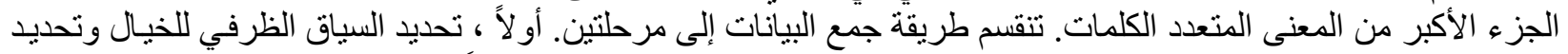

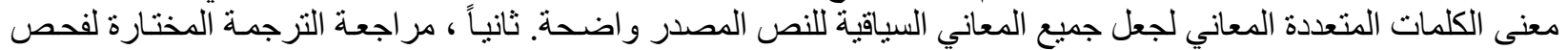

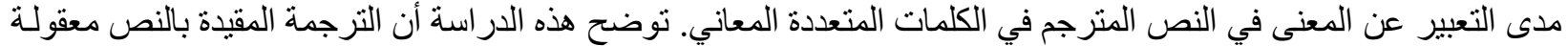

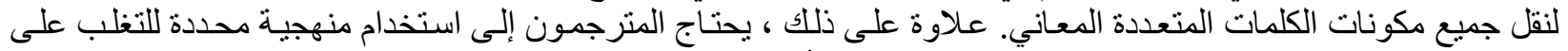

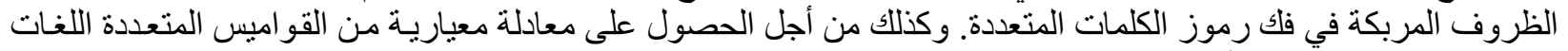
و تعمل وظائف الدر اسة الأسلوبية المقارنة لتحديد دلالة السياق و إدر الك مفهوم الكلمات المتعددة المعاني. الكلمات المفتاحية: الكلمات المتعددة المعاني ,هاري بورتز , رواية خيالية, ترجمة 


\section{Introduction}

Most of English or Arabic words have more than one meaning. Polysemy is the connotation of one word with two or more different meanings. Koskela, A and Murphy, M L (2006) strengthen that more than $40 \%$ of English words have more than one meaning. The semantic changes of polysemous words often add denotations to the language. The term of Polysemy refers to a word or phrase with multiple meanings being in all natural languages. (Bussmann, Routledge Dictionary of Language and Linguistics, 2006). This fact about polysemous words has been verified experimentally in many studies for the reason that arising many assumptions for both theories of semantic and translation. Such semantic and translational concentration, which involves moving and reorganizing elements of information, is one of the most distinctive features of linguistics.

The translation of polysemous words requires interpretive analysis and may imply some semantic changes in the target language(TL). The translator transfers the polysemous words that require referring to the context or the situation where meaning and signification may differ and cause one of the vital puzzles of the lexical semantic. Furthermore, Hogeweg (2009) shows that the meaning of the words may lead to different interpretations in different contexts. Some meanings cannot be clearly grasped and extracted directly because the meaning of the words or expressions may fade to match from one language to another.

Harry Potter books are created for children. Harry Potter and the Philosopher's Stone is the story of a young boy who attends an academy for young wizards and introduces readers to a magical world of wizards and muggles, of sorcery, adventure and fantasy and makes the young boy the perfect hero for a children's story, (Perry, 2003). The language in HP books is that of puns and humour, of invented words, magic spells, regional accents, names of unknown creatures and many more and these results in huge challenges for translators commissioned to translate them. Harry Potter and the Sorcerer's Stone is the first story of the British author JK Rowling's Harry Potter series revolves around the magic of the little magician HP in a little childish context, but it is possible to consider the series to be for all age groups. It was first published on June 30, 1997 in London under the name Harry Potter and the Philosopher's Stone.

This translation of fantasy novels is considered as a kind of literary production in term of SL classification of polysemous words is switched to equivalents, (Makni, F., 2013). To get an understanding into the translation of polysemous words, HP series of fantasy novels that contain polysemous words are related. The aim of choosing HP book is the famous attractiveness of the series over the world. To examine how far they express the TL meaning of the polysemic sense, this study elucidates a methodical study for HP polysemous words that characterize various communicative states. These texts are discussed analytically and pragmatically. The objectives of this study are to find out how polysemous words function in translating the $\mathrm{HP}$, and to improve the way of transforming the polysemous words of HP texts. The trusted and known version of the translation of the Harry Potter and the Philosopher's Stone translated by Saahar 
Jaber Mahmoud(2008) is adopted for the present study. The polysemous words are studied with adopting the most two widespread and confidential online dictionaries: Cambridge EnglishArabic Dictionary (DIC1) and Oxford Advanced Learner's Dictionary (DIC2) to treat the comparative research analysis.

\section{The Nature and Characteristics of Translation Fantasy Novels}

The translation of the fantasy novels needs a vital technique of imposing culture and knowledge, and conveys the familiarities of languages. It is a serious reason of inspiration for readers. Perry (2003) points out that fantasy works embody an imaginary universe comprising events, places, and creatures that could not occur or exist in the realistic world. Etymology plays a key role in the fantasy story. As Landers (2001) explains:

The Harry Potter phenomenon is a once-in-a-generation occurrence. While it's good that it has many young people reading again instead of vegetating in front of a television set or jabbing away at video games, I doubt that it will have much effect on translated children's literature in the English-speaking world. The Harry Potter series, after all, was written in English and takes place in a familiar cultural setting albeit one tinged with magical elements. If anything, its major impact to date has been to stimulate translation of children's fiction from English to other languages. (p. 108)

The challenges of translating fantasy novels indicate a remarkable instance of the indefinable genre. The fantasy literature reflects magical spells in the HP series. The translators establish the procedure of detecting languages, influences, and elves of peoples. As fantasy works play a significant part in language, various methodologies associated with translation of fantasy novels are endeavored (Roostaee, Z., 2010). These approaches involve looking at fantasy novels both at the literal level of language as well as the figurative level. This section focuses on the critical discussions that give insight and awareness of differing arguments, theories and approaches and then thereby identify the variances on those studies.

The sense of rhetorical meaning must be grasped, according to the multistage model of fantasy literature understanding when involving the procedure of translation process. (Khalaf et al., 2015). Furthermore, the literal meaning of the fantasy novels is obviously a matching to the same sense, as the figurative sense of fantasy novels extracts an image of the context of an event in another phase of treating the figurative sense of fantasy novels.

The translation of the fantasy novels cause disputes for translators. The understanding of the rhetorical sense demands various strategies that can be applied to grasp the literal meaning of fantasy novels, (Wandinger, Nikolaus, et al., 2003). Moreover, the close relation between the literal meaning and figurative meaning is fundamental to transfer the precise meaning of fantasy novels. To overcome the problems of mismatching the linguistic structures of translating fantasy novels, the figurative meanings of the SL and TL must be included.

\section{Equivalence in translation of the polysemous words}

Translating polysemous words is not an easy task and accompanies with many linguistic problems generally. Linguistic equivalence connects directly with context. It is the outcome of translation. Tengku and Moindjie (2006) elucidated that equivalence is indeed an important 
procedure that each word conjures up an array of concepts and images to be the basis of translation. The translation theories of equivalence have been improved to ensure obtaining an actual translation. Lörscher (2012) verified that the translation process demands a translation approach to convey the reality of the SL text to the TL text to develop the translation competence in general. However, the process of finding polysemous word equivalence requires an understanding of the components of language and how these components fit together to express meaning. The linguistic meaning of the polysemous word is as something that gives static or objective notation

This fact about polysemous words has demonstrated conceptual understandings and perceptions, socio- cultural expectations. The meaning of the polysemous word is built with denoting to the text, ( Makni, F., 2013). Thus, polysemous word equivalence is associated with a communicative situation. The context constrains and regulates its meaning. Abobaker (2014) adds that translating polysemous word is not changing one word for another. Consequently, the translator faces complications to retrieve precise equivalence from words taken in loneliness.

The linguistic problems may appear when translating the polysemous word from one language into an other because of the corresponding symbols of the polysemous word given from two languages are not arranged identically.

\section{Methodology}

The present study presents further awareness into translating polysemy in the HP and gives a detailed analysis of the interaction between meaning and context against the contextual of the semantic technique in which the translation grasps. Furthermore, the study endeavors to explicate and follow the strategies that the translators need in rendering polysemic words in the HP. Due to the limitations of this study, a number of polysemic words in HP are examined (between 2 and 5) to illustrate the translation similarly or differently. Moreover, the study randomly chooses three polysemic words in Harry Potter and the Sorcerer's Stone as a corpus of the present study. These words are hand, head, and sense. Then, the present study compares how translators render the polysemic words in HP. The study consults two dictionaries: Cambridge English-Arabic Dictionary (DIC1) and Oxford Advanced Learner's Dictionary (DIC2) to determine the polysemy of the literary production that embodied the polysemic sense of the words, which are: The data analysis is divided into two stages. Firstly, determining the situational context of the fantasy and identify the polysemic sense to make clear all the contextual meanings of the source text. Secondly, review the selected translation to examine how far they express the TL meaning of the polysemic sense as shown in figure 1. 


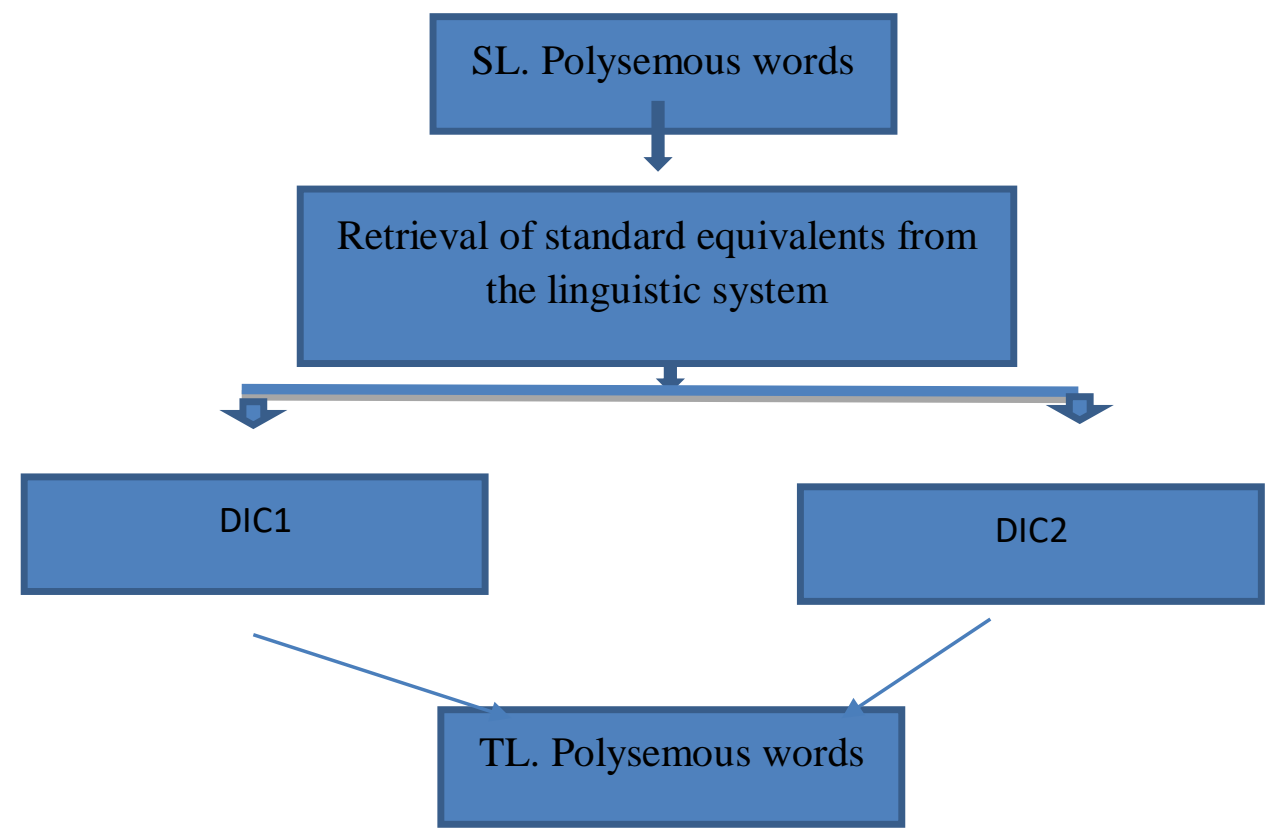

Figure 1. The theoretical framework based on Muthana, Tengku Mahadi, et al., 2015.

Moreover, the stages of analysis illustrate the manipulation of language that directly affects the rhetorical types of fantasy language. The present study contributes even more to provide an appropriate analytical method that can support the translation process of rhetorical types systematically.

\section{Data Analysis}

The present study selects three polysemic words in Harry Potter and the Philosopher's Stone as a sample (hand, head and sense). Not all senses of these words are considered; just selecting some polysemic senses as samples. Besides, the study chooses the translations of the HP Series (Arabic Edition) (Arabic) translated by Saahar Jaber Mahmoud(2008), then it performs a comparative study to evaluate how translator conveys polysemic words as follows:

\section{1. hand}

The word "hand" mentioned in the following examples:

1.SL: "It was a very odd watch. It had twelve hands but no numbers"; p.9

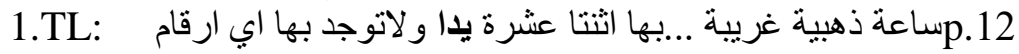

the core meaning of hand as illustrated in sample 1

Dic1: one of the long, thin pieces that point to the numbers on a clock or watch lit. Scorpion of the watch 
Dic2: a part of a clock or watch that points to the numbers

Example: Does anyone have a watch with a second hand?

The translator uses the literal meaning of 'hand' that simply associated with literal meaning. The translator tries to get standard equivalence in multilingual dictionaries or functions on comparative stylistics to determine the contextual connotation and make the sense of polysemous notion more conventional. The translator translates this word in a literal way that destroys its

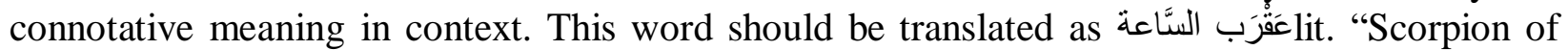
the watch" and not lit. "hand".

2. SL: "he had hands the size of trash can lids", p.11

2.TL: 14وبين ذراعيه الضخمنين لفافة من الملاءات البيضاءplp.14

The core meaning of hand as illustrated in sample 1

Dic1: the part of your body on the end of your arm that has fingers

lit: hand

Dic2: the part of the body at the end of the arm, including the fingers and thumb

Example: I had my hands in my pockets.

3. SL: "Even if I could, I wouldn't. Scars can come in handy." P.11

3.TL: لا احيانا تكون هذه الندوب مفيلة p.14

the core meaning of hand as illustrated in sample 1as follows:

Dic1: useful or easy to use or near or easy to get to

قَريب / فِي مُنَنَاوَل الَيَّْ

عَمَلي / مُفَيد التِ

DIC2: easy to use or to do

Example: It's a nice house and it's handy for the station.

The meaning of hand in (2) above is all associated with the core concept 'physical hand as the part of the body while The adjective 'handy' in (3) is used to denote a metaphorical meaning and can be easily related to useful or easy to use as in Table 1. To guess the precise meaning of polysemic words, the translator intimately deals with knowledge and memory of language to find the precise equivalence of polysemic words. Simple recognition of the relevant equivalence in context may support to match the same meaning in the same message of the SL. Therefore, the bilingual discourse analysis facilitates to translate this type of translation, verify different meanings and convey expressive and core meaning of a polysemic word thoroughly. These three polysemous words are as shown in the Table (1)

Table.1: English definitions and Arabic translations of hand

\begin{tabular}{|c|c|c|c|}
\hline Samples & English meaning & Arabic meaning & Arabic translation \\
\hline $\begin{array}{l}\text { 1.SL:'It was a very odd } \\
\text { watch. It had twelve } \\
\text { hands but no numbers;" } \\
\text { p.9 }\end{array}$ & $\begin{array}{l}\text { Dic1: one of the long, thin } \\
\text { pieces that point to the } \\
\text { numbers on a clock or } \\
\text { watch } \\
\text { Dic2: a part of a clock or } \\
\text { watch that points to the } \\
\text { numbers } \\
\text { (literal translation) }\end{array}$ & $\begin{array}{l}\text { عَقُرَب السئاعة lit. Scorpion of } \\
\text { the watch }\end{array}$ & 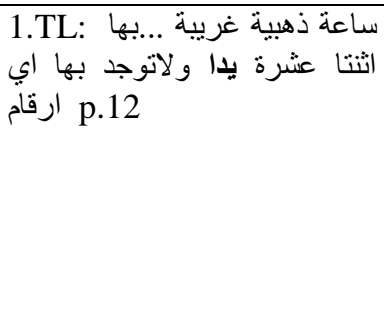 \\
\hline
\end{tabular}




\begin{tabular}{|c|c|c|c|}
\hline $\begin{array}{l}\text { 2. SL: "he had hands the } \\
\text { size of trash can lids," } \\
\text { p.11 }\end{array}$ & $\begin{array}{l}\text { Dic1: the part of your } \\
\text { body on the end of your } \\
\text { arm that has fingers } \\
\text { Dic2: the part of the body } \\
\text { at the end of the arm, } \\
\text { including the fingers and } \\
\text { thumb } \\
\text { (literal translation) }\end{array}$ & يَدّ lit: hand & $\begin{array}{l}\text { 2.TL: لفافين ذن الملاءات الضخمتين أليضاء14 } \\
\text { p.14 }\end{array}$ \\
\hline $\begin{array}{l}\text { 3. SL: "Even if I could, I } \\
\text { wouldn't. Scars can come } \\
\text { in handy." P.11 }\end{array}$ & $\begin{array}{l}\text { Dic1: useful or easy to } \\
\text { use or near or easy to get } \\
\text { to } \\
\text { DIC2: easy to use or to do } \\
\text { (metaphorical } \\
\text { meaning) }\end{array}$ & lit: useful & $\begin{array}{l}\text { 3.TL: لا احيانا تكون هذه الندوب p.14 } \\
\text { فيدة p. }\end{array}$ \\
\hline
\end{tabular}

\section{2. head}

The word "head" is mentioned in the corpus as in the following examples:

1. SL: "Mr. Dursley didn't realize what he had seen -- then he jerked his head around to look again."P.2

The core meaning of 'head' as illustrated in sample 2

Dic1: the part of your body that contains your brain, eyes, ears, mouth, nose, etc.

رَأس

DIC2: "the part of the body on top of the neck containing the eyes, nose, mouth and brain Example: He fell and hit his head on the table."

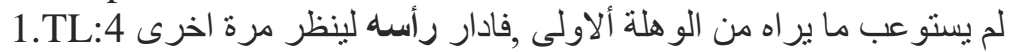

The polysemous word 'head' in (1) above is used to express literally the part of the body on top of the neck to match the same reality.

2. SL: "I know that," said Professor McGonagall irritably. "But that's no reason to lose our

heads.'P.7

Dic1: your mind

عَقْل

DIC2: the mind or brain

Example1: I kept hearing that song in my head.

2.TL:10 قالت ألاستاذة (ماكجونجال) : "أعرف ذللك .. لكنه لبس سببا لنفقد عقولنا

3. SL: "Bill was head boy and Charlie was captain of Quidditch."P.79

Dic1: "the person who is in charge of an organization"

رَئبس

DIC2: the person in charge of a group of people or an organization

Example: Her father is the head of an oil company.

3.TL: كان بيل الطالب المثالي.... و(تشارلي ) كابتن فريق (الكويدنش) 
The polysemous words of 'head' in (1 and 2) comprise figurative connotations and can be exactly denoted to their meanings concluded the equivalent words in English and Arabic. The sense of 'head' refers to one in the duty of a group of people or an association because it is derived from the most important part of the body. The translator uses the same rhetorical meaning that refers to the same sense in the TL as indicated in the Table (2).

Table.2: English definitions and Arabic translations of head

\begin{tabular}{|c|c|c|c|}
\hline Samples & English meaning & Arabic meaning & Arabic translation \\
\hline $\begin{array}{l}\text { 1. SL: "Mr. Dursley } \\
\text { didn't realize what he } \\
\text { had seen -- then he } \\
\text { jerked his head around } \\
\text { to look again."P.2 }\end{array}$ & $\begin{array}{l}\text { Dic1:the part of your } \\
\text { body that contains your } \\
\text { brain, eyes, ears, } \\
\text { mouth, nose, etc. } \\
\text { DIC2: "the part of the } \\
\text { body on top of the neck } \\
\text { containing the eyes, } \\
\text { nose, mouth and brain" } \\
\text { (literal translation) }\end{array}$ & رَأس lit: head & 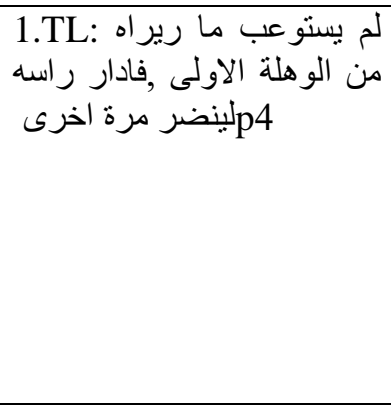 \\
\hline $\begin{array}{l}\text { 2. SL: "I know that," } \\
\text { said Professor } \\
\text { McGonagall irritably. } \\
\text { "But that's no reason to } \\
\text { lose our heads.P.7 }\end{array}$ & $\begin{array}{l}\text { Dic1: your mind } \\
\text { DIC2: the mind or } \\
\text { brain } \\
\text { (metaphorical } \\
\text { meaning) }\end{array}$ & lit: brain & 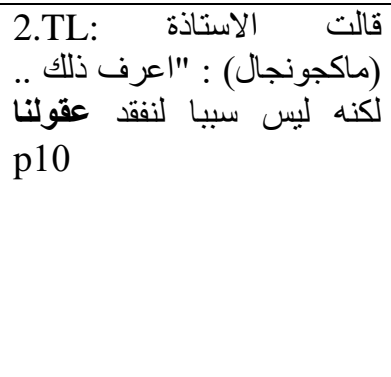 \\
\hline $\begin{array}{l}\text { 3. SL: "Bill was head } \\
\text { boy and Charlie was } \\
\text { captain of Quidditch." } \\
\text { P.79 }\end{array}$ & $\begin{array}{l}\text { Dic1: the person who is } \\
\text { in charge of an } \\
\text { organization } \\
\text { DIC2: the mind or } \\
\text { brain } \\
\text { (metaphorical } \\
\text { meaning) }\end{array}$ & lit: head رَئيس & 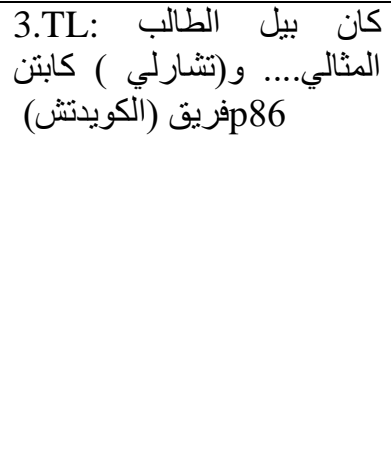 \\
\hline
\end{tabular}

3. sense

The word "sense" is mentioned in the corpus in the following examples:

1. SL: "If Harry hadn't known that the Dursleys had no sense of humor;" P.52 
The core meaning of 'sense' as illustrated in sample 3

Dic1: the ability to understand funny things and to be funny yourself

حِس فُكاه

DIC2: the ability to find things funny or make people laugh.

Example: She has a really good sense of humour.

و لاكنه يعرف جيدا أنه لا يحب الفكاهه:1.TL

2. SL: It must have made sense to Dumbledore, P.9

Dic1:to have a meaning or reason that you can understand

لَه مَعْنى

DIC2: to understand something that is difficult or has no clear meaning

Example: He's written me this note but it doesn't make any sense.

2.TL: non translation

The translator paid no attention to the word ' sense' in (2). She conveys the sense of this word without transferring the SL wording. However, the translator conveys the intended meaning entirely:

3. SL: Shooting stars down in Kent -- I'll bet that was Dedalus Diggle. He never had much sense.P.7

Dic1: the ability to make good decisions and do things that will not make problems

حِسّ

DIC2: "good understanding and judgment; knowledge of what is sensible or practical behaviour"

Example: He had the good sense to book a seat in advance.

$$
\text { p.10 فهو لم يملك يوما ذرة من الادراك }
$$

The polysemous words of 'sense' in (1 and 3) are rendered word for word to the TT. The translation of fantasy novels needs a kind of regulated translation to produce the same equivalents of polysemous words. The translator tries to match the idea of 'sense "knowledge of what is sensible' with a recovery of the standard expression 'الادراك which indicates the same equivalent in TL as indicated in Table (3).

Table.3: English definitions and Arabic translations of sense

\begin{tabular}{|c|c|c|c|}
\hline Samples & English meaning & Arabic meaning & Arabic translation \\
\hline $\begin{array}{l}\text { 1. SL: "If Harry hadn't } \\
\text { known that the } \\
\text { Dursleys had no sense } \\
\text { of humor" ;P.52 }\end{array}$ & $\begin{array}{l}\text { Dic1: the ability to } \\
\text { understand funny } \\
\text { things and to be funny } \\
\text { yourself } \\
\text { DIC2: the ability to } \\
\text { find things funny or } \\
\text { make people laugh. } \\
\text { (metaphorical } \\
\text { meaning) }\end{array}$ & $\begin{array}{l}\text { حسّ فُكاه lit: be funny } \\
\text { yourself }\end{array}$ & $\begin{array}{l}\text { 1.TL: و لاكنه يعرف جيدا انه الفكاهd } \\
\text { يحب الفاه }\end{array}$ \\
\hline $\begin{array}{l}\text { 2. SL: It must have } \\
\text { made }\end{array}$ & $\begin{array}{l}\text { Dic1:to have a meaning } \\
\text { or reason that you can }\end{array}$ & lit: have meaning كَعْنَى lin & 2.TL: non translation \\
\hline
\end{tabular}




\begin{tabular}{|c|c|c|c|}
\hline Dumbledore, P.9 & $\begin{array}{l}\text { understand } \\
\text { DIC2: to understand } \\
\text { something that is } \\
\text { difficult or has no clear } \\
\text { meaning } \\
\text { (metaphorical } \\
\text { meaning) }\end{array}$ & & \\
\hline $\begin{array}{l}\text { 3. SL: "Shooting stars } \\
\text { down in Kent -- I'll bet } \\
\text { that was Dedalus } \\
\text { Diggle. He never had } \\
\text { much sense."P.7 }\end{array}$ & $\begin{array}{l}\text { Dic1:the ability to } \\
\text { make good decisions } \\
\text { and do things that will } \\
\text { not make problems } \\
\text { DIC2: "good } \\
\text { understanding and } \\
\text { judgement; knowledge } \\
\text { of what is sensible or } \\
\text { practical behaviour" } \\
\text { (metaphorical } \\
\text { meaning) }\end{array}$ & lit: sense حِسّ & فهو لم يملك يوما ذرة من الادراك \\
\hline
\end{tabular}

\section{Conclusions}

Polysemy refers to two or more related meanings. Thus, the translators may confuse and cause problems working with a category of polysemous words. The translation of HP utilizes various rhetorical structures that product in an efficient and inspiring style. Linguistic and rhetorical structures contest the translators of the polysemous words in HP. The translator intimately deals with knowledge and memory of language to find the precise equivalence of polysemic words. To guess the precise meaning of polysemic words, simple recognition of the relevant equivalence in context may support to match the same meaning in the same message of the SL. Therefore, the bilingual discourse analysis facilitates to translate this type of translation, verify different meanings, convey expressively, and extract the meaning of a polysemic word thoroughly. Thus, the translator tries to get standard equivalence in multilingual dictionaries or functions on comparative stylistics to determine the contextual connotation and make the sense of polysemous notion more conventionally. 


\section{References}

Al-Khamash, S. (1991). 'Addad': A study of homo-polysemous opposites in Arabic (Order No. 9203427). Available from ProQuest Dissertations \& Theses Global. (303922173). Retrieved from https://search.proquest.com/docview/303922173?accountid=14645

Bussmann, H., Trauth, G. \& Kazzazi, K. (2006). Routledge dictionary of language and linguistics. London: Routledge.

Cambridge University (2019). Cambridge English-Arabic Dictionary. [online] Dictionary.cambridge.org. Available at: https://dictionary.cambridge.org/dictionary/english/ [Accessed 10 Jan. 2019].

Cambridge University (2019). Oxford Advanced Learner's Dictionary. [online] Dictionary.cambridge.org. Available at: https://dictionary.cambridge.org/dictionary/english/ [Accessed 10 Jan. 2019].

Hogeweg P. (2009) Multilevel Modeling of Morphogenesis. Springer, Berlin, Heidelberg

J. K. Rowling(2008). Harry Potter Series (Arabic Edition) (Arabic). Nahdet Misr Publishing Group; 12th edition, translated by Saahar Jaber Mahmoud(2008)

Khalaf, Muthana H., Tengku Mahadi, T. \& Moindjie, Mohamed.(2015). A comparative analytical study of translation the concept of wisdom in some selected verses of Quran. In T.

Khalaf, Muthana H., Tengku Mahadi, T. \& Moindjie, Mohamed.(2015). A comparative analytical study of translation the concept of wisdom in some selected verses of Quran. In T. Mahadi, \&C. Thomas (Eds.). The sixth international language learning conference. Paper presented at School of Languages, Literacies and Translation, 2-4 November 2015 (pp.140-156). University Sains Malaysia, Penang.

Koskela, A and Murphy, M. L (2006) Polysemy and homonymy. In: Brown, Keith, Anderson, Anne H, Bauer, Laurie, Berns, Margie, Hirst, Graeme and Miller, Jim (eds.) Encyclopedia of language and linguistics (2nd ed). Elsevier, pp. 742-744. ISBN 9780080442990 (set) 9780080443652 (v. 9)

Landers (2001) Literary Translation: A Practical Guide. Multilingual Matters, New Jersey City University.

Lörscher, W. (2012). Bilingualism and translation competence. SYNAPS - A Journal of Professional Communication, 27/2012,1-15.

Mr. Abobaker Ali, M. Alsaleh Brakhw, Dr. Munif Zarirruddin Fikri bin Nordin, Transferring POLYSEMIC Words from Arabic into English: A comparative Study of Some Samples from the Holy Quran. Aust. J. Basic \& Appl. Sci., 8(23): 38-43, 2014

Makni, F. (2013) Teaching Polysemous Words To Arab Learners: A Cognitive Linguistic Approach. University of the West of England, UK. 
Perry, Phyllis J. (2003). Teaching Fantasy Novels: From the Hobbit to Harry Potter and the Goblet of Fire. TEACHER IDEAS PRESS Portsmouth, NH,USA.

Roostaee, Z. (2010). An intercultural study: The reception of J. K. rowling's the "Harry Potter" book series in iran (Order No. MR70800). Available from ProQuest Dissertations \& Theses Global. (855625638). Retrieved from https://search.proquest.com/docview/855625638?accountid=14645

Tengku Mahadi, Tengku Sepora and Moindjie, Mohamed. (2006). Text- wise in translation. Malaysia Pearson Malaysia Sdn. Bhd.

Wandinger, Nikolaus, et al. "Harry Potter and the Art of Theology: A Theological Perspective on J. K. Rowling's Novels. Part One: Healing, Grace and Original Sin." Milltown Studies 52 (Winter 2003): 1-26. Print. 